\title{
Determining Factors Affecting Subscribers' Preferences in Selecting Telecommunication Operators by Fuzzy Multiple Criteria Decision Making Model (Case study: Students of Ferdowsi University)
}

\author{
Mohammad Reza Shahraki ${ }^{1 *}$, Farzad Fadaei ${ }^{2}$ \\ ${ }^{1}$ Assistant Professor, Department of Industrial Engineering, University of Sistan and Baluchestan \\ mr.shahraki@eng.usb.ac.ir \\ ${ }^{2}$ Master Students of Civil Engineering, University of Sistan and Baluchestan
}

\begin{abstract}
The main purpose of any organization is to create a kind of stable relationship between the product and the customers, the result of which will be the commitment and loyalty of customer to the product and organization. Creating such a commitment takes place in a process that involves customer familiarity with the product, knowing it, and then the product's preference. The purpose of conducting this research is to provide a model of subscribers' preferences in selecting mobile phone operators. The research population of this study is the students of the Ferdowsi University of Mashhad, who use the two operators of Irancell and Hamrahaval simultaneously. By investigating the research literature, 22 criteria of the most important factors affecting subscribers' preferences in selecting mobile phone operators were identified and the questionnaire was distributed among sample members. Fuzzy data obtained from the questionnaires has been defuzzificated and the criteria have been ranked by the aid of VIKOR method. The results show that the antenna coverage factors in the depth and height have the highest priority and trademark has the lowest priority. By using the results of VIKOR method in the importance-performance matrix, the performance of the two operators of Irancell and Hamrahaval was analyzed. The results show that in the Hamrahaval operator, the factors of "antenna coverage in the depth and height", "speed of performing services in the centers", "SIM card price", "the modernity of services based on the technology of the day", "the quality in providing value-added services", "performing services at every hour of the night and day" were of great importance, but the performance of the company has been poor in relation to these criteria. In the operator of Irancell, there is not any satisfactory performance in relation to the factors of "offering awards and discounts on the use of services", and "calls price".
\end{abstract}

Keywords - Subscribers' Preferences, Services, Operator, Fuzzy Theory, VIKOR Method, Importance Performance Matrix

\section{Introduction}

In the information era, telecommunication industries have one of the highest indicators of growth among other industries. Among various communication and telecommunication industries, one of the fastest growth rates belongs to the mobile service industry, that its share in the daily communications of individuals is tremendously rising and surpassing the fixed-line phone. This high-speed growth is not only due to the innovation in mobile communication technology, but mainly due to the intense competition of operators, under minimum regulations governing the market of this industry. The mobile service market also show a remarkable growth of itself; the growth that its cause cannot only be regarded due to the increase in the number of subscribers, and ignoring the increasing variety of services and new arenas of competition resulted from them. This simultaneous growth of the industry and the marketalong with trying to acquire new customers by using their preferences and behaviors, has led operators to gradually lead their marketing towards attracting the customers of other operators (Kim \& Yoon, 2004). Preserving old customers, especially in the mobile phone market, except the costs of attracting customer, has the opportunity value for the operator, which means that the suppliers are able to provide additional and new services for the customer during the maintenance period and acquiring more income. For this reason, the loss of existing customer will not only result in lower incomes and the imposition of the cost of attracting new customer to the enterprise, but also results in the loss of potential incomes. Therefore, with the growth of telecommunication companies globally and the maturity of markets of such services, customers' turning away management has become one of the major concerns in these companies (Kim \& Jeon, 2004). 
This research investigates the issue of subscribers' preferences in selecting the telecommunication operators of Irancell and Hamrahaval, and tries to identify the factors affecting the subscribers' preferences in selecting operators. After identifying these factors, by using the VIKOR method, it evaluates and prioritizes the factors affecting the subscribers' preferences in selecting telecommunication operators, and by using the importanceperformance matrix, analyzes the performance of the two operators of Irancell and Hamrahaval.

\section{Statement of the Problem}

Organizations cannot continue their life without regarding the customer's demand. Paying attention to the customer's demand and preferences leads to his satisfaction and loyalty and, as a result, increases the reputation and credit of the company as well as the future profitability of the company. It is important to be informed of the customers' preferences for predicting and controlling their behavior. The customer's preference is due to an attitude that he has towards a product or specific brand (Rezaian and Karimi, 2010).

Consumers' behavior preferences are appropriate indicator for assessing their intrinsic and spiritual behaviors (Tang et al., 2008). Therefore, despite the fact that in most of the cases, it is difficult to recognize consumers' preferences, but recognizing and predicting consumers' behavior is one of the most important duties of the marketers (Fullerton \& Punj, 2004). The managers of organizations must distinguish what is important for their customers in the target market and understand the criteria for product comparison in the selection process. Organizational strategies must be formed based on the recognition of thoughts, feelings and behaviors of consumers (Samadi, 2007).

In the telecommunication companies, with regard to the mobile phone technology growth and the increasing use of it and broad popular acceptance, the mobile phone market has become competitive and the number of mobile phone service providers has increased and the market has exited from being monopoly. In the competitive market, there is an effort to attract new customer and, on the other hand, the existing customer should be preserved. Some operators gain significant information about customers and, by analyzing it, acquire accurate understanding of the customers' preferences. Moreover, in a growing market, attracting new customer needs to make them turn away from other operators and competitors, which requires more attractive stimuli. Therefore, the telecommunication service provider company should identify the factors affecting the mobile phone customers' preferences, so that not only it prevents its customers' turning away, but also attracts new customers.

\section{Research History}

Telecommunication services are qualitatively and quantitatively expanding in the world and play an important role in the development of various communities. The use of telecommunication services in various countries and communities should be done with attention to the particular features of communities so that it corresponds with the needs of consumers. For this purpose, it is essential that the use and expansion of telecommunication be combined with scientific and comprehensive studies (Mulla Ali Kei and Ahmadi, 2002). Since subscribers' satisfaction and loyalty are the key features of the success of mobile phone operators, mobile phone service providers should seek the needs and preferences of subscribers in order to obtain subscribers' satisfaction and loyalty. Song and Kim (2001) measured the impact of mobile market structure transformation on customers' turning away by a simulation method in Korea. Choi et al. (2001) investigated the impact of business strategies of the five major mobile service providers in Korea on customers' loyalty. Kim \& Kwon (2003) studied the factors that customers consider when selecting their mobile phone operator. The result of these researches indicate the effect of inter-network calls discount as well as the quality of establishing communication by operators on the customers' decision in their selection. Kim and Yoon (2004) conducted a survey on the users of major mobile phone operators in South Korea and identified loyalty characteristics of subscribers. They showed in this research that the possibility of changing operator by the customer depends on his level of satisfaction with operator services features including call quality, tariffs level, providing phone by operator, trademark credit in addition to the revenue and the time duration of subscription. Factors such as call quality, the type of phone provided by operator and trademark credit also affect customer loyalty. The lack of a significant relationship between the time duration of subscription and the activities that confirm customer loyalty indicates the existence of a locking effect among customers that can be called false loyalists (those who are not willing to end the subscription only and only for avoiding the costs of changing operator).

Hafeez and Hasnu (2010), in a research conducted in the mobile phone service market, concluded that customers' perceptions of price fairness, with regard to their expectations, quality of services and the price levels of competitors affect on the choices, satisfaction and then loyalty of customers. Sehat et al. (2012) confirmed the impact of price on customers' loyalty. Gerpott et al. (2001) research on the German mobile phone market showed that preserving customer, his loyalty and satisfaction are interlinked causally, and the cost of mobile phone services and the feeling of benefit from the provided services have an important impact on customer loyalty. They also showed that the quality of mobile phone services for subscribers includes voice quality, voice continuity, conversation connection speed, and coverage level and antenna coverage. Ahn et al (2006) conducted a research on customers' turning away analysis; by using the data related to the subscribers' 
transactions and payments, this research investigated factors of customers' turning away and recognized the customers' dissatisfaction, the costs of change, and the amount of service consumption effective on their decision to remain or turning away. Sabahi (2009) conducted a comparative investigation on the satisfaction ratio of subscribers with the services of mobile phone operators in public universities. Sheikhzadeh et al. (2013) have compared customers' satisfaction with the value added services of the two mobile phone operators in Iran. Also, Babakus and Boller (1992) have used SERVQUAL model to measure the quality of services and to investigate its impact on customers' satisfaction and purchase preferences.

Table 1: Service Quality Dimensions in the Mobile Phone Service Industry

\begin{tabular}{|c|c|}
\hline $\begin{array}{c}\text { Service Quality } \\
\text { Dimensions }\end{array}$ & Researchers \\
\hline $\begin{array}{c}\text { Network Quality } \\
\text { (Lim,Widdows, \& Park, 2006); (Negi, 2009);(Pezeshki, Mousavi, \&Grant, 2009); } \\
\text { (Santouridis \& Trivellas, 2010) }\end{array}$ \\
\hline $\begin{array}{c}\text { Added Value } \\
\text { Services }\end{array}$ & $\begin{array}{c}\text { (Gunjan et al., 2011); (Jahanzeb, Fatima, \& Khan, 2011); (Lim et al.,2006); } \\
\text { (Santouridis \& Trivellas, 2010) }\end{array}$ \\
\hline Issuing Bill & (Krishnan \& Kothari, 2008); (Lim et al., 2006); (Pezeshki et al., 2009); (Santouridis \\
\& Trivellas, 2010)
\end{tabular}

\section{The Research Executive Framework}

The present research is applied in respect of purpose, and it is among the survey researches in terms of conducting method. The research statistical population is composed of the subscribers of the two operators of Irancell and Hamrahaval in the Ferdowsi University of Mashhad, who are users with diverse interests, from different parts of the country, while familiar with many services related to the operators. The research questionnaire was provided to the students who have used the services of both operators concurrently for at least six months. Accordingly, by using the Cochran formula, the number of survey sample was determined 475 people. The items forming the questionnaire were extracted through investigating previous researches, and by referring to telecommunication experts and interviewing with a number of subscribers, and its content validity was confirmed by professors and experts. Cronbach's alpha coefficient was used to measure the reliability of questionnaire and its calculated value was 0.89. After collecting data from the research population, at the next stage, regarding that the data of questionnaires was fuzzy; this data was converted to explicit numbers.

\section{Fuzzy Theory}

In the real world, most phenomena, variables, and concepts have inexact nature and do not adhere to the principles governing the theory of definite sets. Lotfizadeh, for the first time, by introducing fuzzy theory, performed inexact data modeling by mathematical equations (Zadeh, 1967). The fuzzy theory is used to express uncertainty created based on multi-value logic.

\section{1 Triangular Fuzzy Number}

A fuzzy number $\widetilde{A}=\left[a_{1}, a_{2}, a_{3}\right]_{\text {in a way that }}-\infty \leq a_{1} \leq a_{2} \geq a_{3}$ and $a_{1}, a_{2}, a_{3} \in R$ are expressed as fuzzy subsets in $\mathrm{R}$ has membership function of $f(\tilde{A}(x))$. The membership function of $f(\widetilde{A}(x))_{\text {is a continuous image of } \mathrm{R} \text { to the closed range of }} f(\tilde{A}(x))_{=0 ;[0,1] .} A=\left[a_{1}, a_{2}, a_{3}\right]_{\text {is }}$ defined as a triangular fuzzy number, if $\mathrm{f}(\mathrm{A}(\mathrm{x}))$ is as equation (1). 


$$
f_{A}(x)=\left\{\begin{array}{c}
\frac{x-a_{1}}{a_{2}-a_{1}}, a_{1} \leq x \leq a_{2} \\
\frac{x-a_{3}}{a_{2}-a_{3}}, a_{2} \leq x \leq a_{3} \\
0
\end{array}\right\}
$$

\subsubsection{Standard Mathematical Operations in the Fuzzy Set}

The equations (2), (3), (4) and (5) show standard mathematical operations for fuzzy numbers of $\widetilde{A}=\left[a_{1}, a_{2}, a_{3}\right]$ and $\widetilde{B}=\left[b_{1}, b_{2}, b_{3}\right]$, and the non-fuzzy number of $\mathrm{n}$ :

$$
\widetilde{A}+\widetilde{B}=\left[a_{1}+b_{1}, a_{2}+b_{2}, a_{3}+b_{3}\right]
$$

$$
\widetilde{A}-\widetilde{B}=\left[a_{1}-b_{1}, a_{2}-b_{2}, a_{3}-b_{3}\right]
$$

$$
\begin{aligned}
& \widetilde{A} \otimes \widetilde{B}=\left[a_{1} b_{1}, a_{2} b_{2}, a_{3} b_{3}\right] \\
& \left.\widetilde{A} \otimes n=\left[a_{1} n, a_{2} n, a_{3} n\right]\right]
\end{aligned}
$$

Defuzzification is the method of converting a set of fuzzy numbers into non-fuzzy values. There are various methods for converting a fuzzy set to a classical set with a definite value. The " $\alpha$ " cutting method is among the methods of converting a fuzzy set to a definite set (Shavandi, 2006). In this research, the " $\alpha$ " cutting method with the aid of ADAMO indicator is used for defuzzification.

\section{2 VIKOR Method}

This method has been prepared based on a collective agreement method and by having conflicting criteria, is generally used to solve discrete issues. In fact, VIKOR method prioritizes options by evaluating options based on the criteria. In this model, the criteria are not weighed, but the criteria are evaluated through other methods, and then the options are ranked according to the criteria and by combining in the value of criteria (Huang, 2009). In the VIKOR method, having formed the decision matrix, in order to normalize it, the linear non-scaling method is used (equation 6).

$$
f_{i j}=\frac{x_{i j}}{\sqrt{\sum_{i=1}^{m} x_{i j}^{2}}}
$$

In the next step, the positive and negative ideal value of each indicator is calculated from the existing values by using equations (7) and (8).

$$
\begin{aligned}
& f_{j}^{+}=\max _{i}\left(f_{i j}\right) \\
& f_{j}^{-}=\min _{i}\left(f_{i j}\right)
\end{aligned}
$$

Then $\mathrm{Qi}, \mathrm{Ri}$, and $\mathrm{Si}$ are calculated by using equations (9), (10), (11). In these equations, $\mathrm{Ri}$ and $\mathrm{Si}$ are respectively the desirable and undesirable values of each one of the options, and as the weight of each one of the criteria. 
(9)

$$
S_{i}=\sum_{j=1}^{m} \frac{w_{j}\left(f_{j}^{+}-f_{i j}\right)}{\left(f_{j}^{+}-f_{j}^{-}\right)}
$$

$$
\begin{aligned}
& R_{i}=\max _{j}\left(\frac{w_{j}\left(f_{j}^{+}-f_{i j}\right)}{\left(f_{j}^{+}-f_{j}^{-}\right)}\right) \\
& Q_{i}=v\left(\frac{S_{i}-S^{*}}{S_{i}-S^{*}}\right)+(1-v)\left(\frac{R_{i}-R^{*}}{R_{i}-R^{*}}\right)
\end{aligned}
$$

In equation (11), Qi is the value of VIKOR indicator for the $\mathrm{i}$ option; it is the maximum group desirability that is usually considered equal to 0.5 . In the next step, the options are arranged based on $\mathrm{Si}, \mathrm{Ri}$, and Qi.

$$
R^{-}=\operatorname{Max}_{i}\left(R_{i}\right)
$$

$$
\begin{aligned}
& R^{*}=\operatorname{Min}_{i}\left(R_{i}\right) \\
& S^{-}=\operatorname{Max}_{i}\left(S_{i}\right) \\
& S^{*}=\operatorname{Min}_{i}\left(S_{i}\right)
\end{aligned}
$$

In the final step of the VIROK technique, the options are arranged in three groups from small to large, based on the values of $\mathrm{Q}, \mathrm{R}$, and $\mathrm{S}$. The best option is the one that has the smallest $\mathrm{Q}$ provided that the two following conditions are established:

First Condition (Acceptance Feature): If options A1 and A2 among m option have the first and second ranks, the following equation should be established:

$$
\begin{gathered}
Q\left(A^{[2]}\right)-Q\left(A^{[1]}\right) \geq D Q \\
D Q=\frac{1}{m-1}
\end{gathered}
$$

Second Condition (Acceptance Stability in Decision Making):Option A1 should be recognized as the top rank in at least one of the $\mathrm{R}$ and $\mathrm{S}$ groups. If the first condition is not established, both options are the best options. If the second condition is not established, option A1 and A2 are both chosen as the top options.

\section{3 Importance-Performance Analysis Method}

The importance-performance analysis method is an effective tool for evaluating the competitive position of the organization, identifying the progress opportunities, and also designing marketing strategies and offering purposeful services (Martilla \& James 1977). Through the formation of a two dimensional matrix that its vertical axis shows customers' perceptions of the performance (quality) of each feature and the horizontal axis indicate the importance of that feature in customers' decision making, effective suggestions can be presented to the managers (figure 2). 


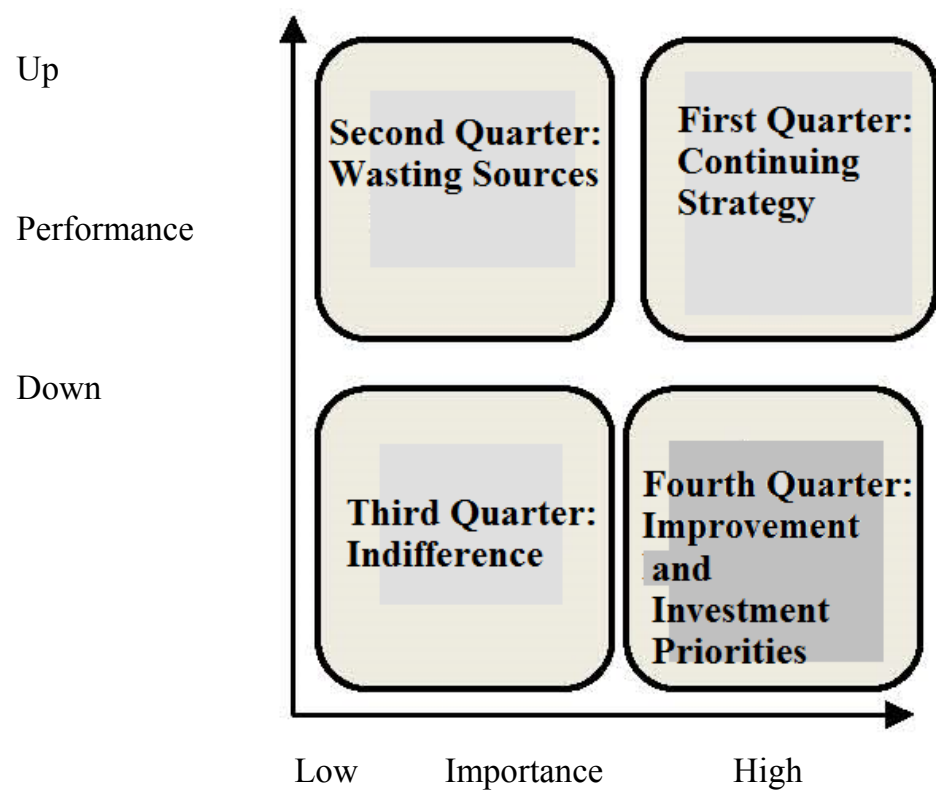

Figure 2: Importance-Performance Matrix (Mattila-James, 1977)

Importance-Performance Matrix is divided into four areas through the mean score of the importance and performance of features. Features located in the first quarter (high importance and performance) represent the strengths and competitive advantage of the organization; the appropriate strategy for this group of features is to maintain the current strategy. The features located in the second quarter (low importance-high performance) indicate the waste of sources allocated to these features, and the resources available can be better used in another area. The third quarter of this matrix is called the area of indifference, because it contains features with low importance and performance, and the appropriate strategy for them is ignorance and lack of investment. The fourth quarter of this matrix (high importance-low performance) will encompass features in itself that indicate weaknesses of the organization and improvement and investment priorities (Azzopardi and Nash, 2012).

\section{Data Analysis}

To analyze the data by using the VIKOR method, the most important factors affecting subscribers' preferences in selecting mobile phone operators are extracted and by using the importance-performance matrix, the performance status of the two operators of Irancell and Hamrahaval in respect of factors affecting subscribers' preferences is investigated, and the factors that need to be improved are identified.

The first step is the formation of a decision making team and determining the weight of team members. In this research, the members of decision making team are consumers of the services of operators, and since the subscribers' use ratio of services types is different, the value of their views is different with each other. Therefore, for each of their viewpoints, we consider the weight. This weight is determined by using the question raised in the questionnaire and asking the respondents to state how much they use mobile phone services in average in one week. By using the obtained data, the range of data is between 5 and 500 minutes and considering the telecommunication experts' viewpoints, the amount of subscribers' use of services was divided into three sections of low, high, and medium, and hence the viewpoint weight of each of the respondents is obtained. These weights are shown as triangular fuzzy scores $\mathrm{A}(\mathrm{X})$. The criterion of "the amount of customers' use of services" is defined as three modes of poor, medium, and good, stated by fuzzy scores. The poor group is considered from 5 to 60 , and we have:

$$
A(x)=\left\{\begin{array}{ccc}
\frac{x-5}{32-5} & \text { for } x \in[5,32] \\
1 \quad \text { for } & x=32 \\
\frac{60-x}{60-32} & \text { for } x & \text { otherwise } \\
0 &
\end{array}\right.
$$


We consider the " $\alpha$ " cutting equal to 0.5 , and obtain the ADAMO indicator for this triangular fuzzy score, and hence the definite value of this triangular fuzzy score is calculated. We repeat this operation for other triangular fuzzy scores. The ADAMO indicator for each triangular fuzzy score is as follows. Assume that $A=(1, s, r)$ has been a triangular fuzzy score, in which $\mathrm{x}$ is axis (center), 1 is down bound, and $\mathrm{r}$ is upper bound (Shavandi, 2006).

$\mathrm{AD} \alpha=\mathrm{s}+(1-\mathrm{a})$

AD $0.5=62$

We consider the medium amount of use from 32 to 200 , and we have:

$$
A(x)=\left\{\begin{array}{ccc}
\frac{x-32}{116-32} & \text { for } & x \in[32,116] \\
1 & \text { for } & x=116 \\
\frac{200-x}{200-116} & \text { for } & x \in[116,200] \\
0 & \text { otherwise }
\end{array}\right.
$$

We consider the triangular fuzzy score related to the good group from 116 to 500 and we have:

$$
A(x)=\left\{\begin{array}{ccc}
\frac{x-116}{308-116} & \text { for } x \in[116,308] \\
1 \quad \text { for } & x=308 \\
\frac{500-x}{500-308} & \text { for } x & \in[308,500] \\
0 & \text { otherwise }
\end{array}\right.
$$

AD $0.5=558$

Then, the group multiplies the amount of service consumption of each group of people in the ADAMO indicator related to that group to obtain the weight of each individual, and then the weights are normalized.

In order to identify the factors affecting the subscribers' preferences in selecting mobile phone operators, firstly, by a comprehensive overview of the background and interviewing with experts and a number of subscribers who used mobile phone services for at least 6 months, the most important effective factors were identified and extracted. The identified factors include 22 criteria that have been presented in table 2 . 
Table 2: Criteria Affecting Subscribers' Preferences in Selecting Operator

\begin{tabular}{|c|l|c|}
\hline No. & \multicolumn{1}{|c|}{ Criteria } & $\begin{array}{c}\text { Abbreviation } \\
\text { Symbol }\end{array}$ \\
\hline 1. & Trademark Credit & $\mathrm{X} 1$ \\
\hline 2. & Offering awards and discounts in using services and selecting a SIM card & $\mathrm{X} 2$ \\
\hline 3. & Sound quality during a conversation (crosstalk, noise, permanent occupation) & $\mathrm{X} 3$ \\
\hline 4. & Continuation of conversation & $\mathrm{X} 4$ \\
\hline 5. & Coverage in all parts of the country & $\mathrm{X} 5$ \\
\hline 6. & The connection speed of conversation & $\mathrm{X} 6$ \\
\hline 7. & Quality in offering services related to value added services & $\mathrm{X} 7$ \\
\hline 8. & Antenna coverage in height (tower, mountain, etc.) & $\mathrm{X} 8$ \\
\hline 9. & Antenna coverage in depth (tunnel, valley, etc.) & $\mathrm{X} 9$ \\
\hline 10. & $\begin{array}{l}\text { Offering services online and without needing to refer the telecommunication } \\
\text { offices }\end{array}$ & $\mathrm{X} 10$ \\
\hline 11. & Payment tariffs & $\mathrm{X} 11$ \\
\hline 12. & SIM card price & $\mathrm{X} 12$ \\
\hline 13. & Conversations price & $\mathrm{X} 13$ \\
\hline 14. & Inner network calls discount & $\mathrm{X} 14$ \\
\hline 15. & Support and after-sales service in all parts of the country & $\mathrm{X} 16$ \\
\hline 16. & How to deal with company's employees and telecommunication offices & $\mathrm{X} 17$ \\
\hline 17. & Number of communication service offices & $\mathrm{X} 18$ \\
\hline 18. & $\begin{array}{l}\text { Up-to-date services based on technology (such as the internet, video } \\
\text { communication, etc.) }\end{array}$ & $\mathrm{X} 19$ \\
\hline 19. & Performing services at any time of the night and day & $\mathrm{X} 20$ \\
\hline 20. & $\begin{array}{l}\text { Variety of services (call transfer, voice mail, fax, international roaming, MMS, } \\
\text { etc.) }\end{array}$ & $\mathrm{X} 21$ \\
\hline 21. & Sending and receiving message & $\mathrm{X} 22$ \\
\hline 22. & The speed in performing services at the centers & \multicolumn{1}{|c|}{. } \\
\hline
\end{tabular}

In order to rank these criteria and factors, the questionnaires were distributed among the students of Ferdowsi University. After collecting the questionnaires, the data from the fuzzy mode was converted to explicit data by using the alpha cutting method, and then by using equation (6), the data was normalized in the VIKOR method. Table (3) shows a part of the normalized values of the primary matrix of the respondents' viewpoint.

Table 3: Normalized Decision Making Matrix

\begin{tabular}{|c|c|c|c|c|c|c|c|c|c|c|c|c|c|c|}
\hline & $\gtrless$ & $\underline{x}$ & 离 & $\underset{\omega}{x}$ & $\stackrel{\rtimes}{\not}$ & u & えू & 爻 & $\underset{\infty}{x}$ & ઢ & $\frac{x}{0}$ & & $\underset{N}{X}$ & $\underset{N}{\stackrel{N}{N}}$ \\
\hline ZZ & $\begin{array}{l}\text { : } \\
\dot{8}\end{array}$ & $\begin{array}{l}0 \\
\dot{\Phi} \\
\dot{\infty}\end{array}$ & $\begin{array}{l}0 \\
\text { un } \\
\vec{d}\end{array}$ & 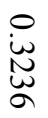 & 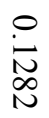 & $\begin{array}{l}0 \\
\dot{u} \\
\stackrel{+}{\Delta} \\
\infty\end{array}$ & $\begin{array}{l}\stackrel{0}{N} \\
\stackrel{人}{+}\end{array}$ & $\begin{array}{l}\stackrel{0}{\vec{D}} \\
\stackrel{\infty}{\perp}\end{array}$ & $\begin{array}{l}0 \\
\dot{N} \\
\infty \\
\&\end{array}$ & $\begin{array}{l}0 \\
\dot{\text { }} \\
\infty \\
\infty\end{array}$ & $\stackrel{\stackrel{0}{N}}{\stackrel{\infty}{\infty}}$ & i & $\stackrel{\stackrel{\circ}{N}}{\stackrel{\Xi}{v}}$ & $\stackrel{\stackrel{0}{\vec{N}}}{\underset{\sim}{\Delta}}$ \\
\hline 忈 & $\begin{array}{l}\dot{8} \\
\dot{8}\end{array}$ & $\begin{array}{l}0 \\
\dot{w} \\
u \\
t \\
0\end{array}$ & $\begin{array}{l}0 \\
\dot{y} \\
\dot{y} \\
+\end{array}$ & 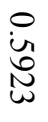 & $\begin{array}{l}\text { i } \\
\text { 定 } \\
\text { N }\end{array}$ & $\begin{array}{l}\dot{0} \\
\dot{\leftrightarrow} \\
\stackrel{\leftrightarrow}{\infty}\end{array}$ & $\begin{array}{l}0 \\
\dot{\sim} \\
\text { 心 } \\
\text { un }\end{array}$ & 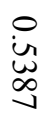 & $\begin{array}{l}0 \\
\dot{\sim} \\
\stackrel{\sim}{0}\end{array}$ & $\begin{array}{l}0 \\
\dot{\text { N}} \\
\infty \\
\infty\end{array}$ & $\begin{array}{l}\text { 崩 } \\
\text { ò }\end{array}$ & i & 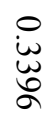 & $\begin{array}{l}\text { i } \\
\text { i. } \\
\text { Iิ }\end{array}$ \\
\hline z & $\begin{array}{l}\dot{0} \\
\dot{y} \\
\dot{y}\end{array}$ & $\begin{array}{l}\text { ㅇ } \\
\dot{+} \\
\dot{\infty}\end{array}$ & $\begin{array}{l}0 \\
\dot{u} \\
\text { un }\end{array}$ & 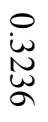 & $\begin{array}{l}\text { o } \\
\dot{y} \\
\dot{\rho} \\
\dot{y}\end{array}$ & $\begin{array}{l}\dot{0} \\
\dot{n} \\
\dot{\Delta} \\
\infty\end{array}$ & $\begin{array}{l}0 \\
\dot{u} \\
\text { un } \\
u\end{array}$ & $\begin{array}{l}0 \\
\dot{N} \\
\stackrel{+}{\omega}\end{array}$ & $\begin{array}{l}\text { O } \\
\text { N } \\
\infty \\
\&\end{array}$ & $\begin{array}{l}0 \\
\dot{y} \\
\text { N } \\
\infty\end{array}$ & $\begin{array}{l}\circ \\
\dot{\omega} \\
\stackrel{8}{8}\end{array}$ & i & 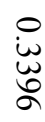 & $\begin{array}{l}0 \\
\text { i. } \\
\text { tे }\end{array}$ \\
\hline$\underset{\perp}{\not}$ & $\begin{array}{l}\stackrel{8}{0} \\
\text { ă }\end{array}$ & $\begin{array}{l}\dot{0} \\
\dot{+} \\
\dot{0}\end{array}$ & $\begin{array}{l}\text { in } \\
\text { w } \\
\vec{\Delta}\end{array}$ & $\begin{array}{l}\text { i } \\
\text { i. } \\
\text { W }\end{array}$ & $\begin{array}{l}0 \\
\dot{u} \\
\dot{o} \\
\dot{\varphi}\end{array}$ & $\begin{array}{l}\text { D } \\
\infty \\
\infty \\
\infty \\
\infty\end{array}$ & $\begin{array}{l}\stackrel{0}{\infty} \\
\infty \\
\infty\end{array}$ & $\begin{array}{l}0 \\
\dot{\vec{d}} \\
\infty \\
\infty\end{array}$ & $\begin{array}{l}\stackrel{0}{\Delta} \\
\dot{\infty} \\
\stackrel{y}{U}\end{array}$ & $\begin{array}{l}\stackrel{0}{D} \\
\dot{D} \\
\text { U. }\end{array}$ & 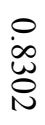 & i & $\begin{array}{l}\dot{w}_{\tilde{D}} \\
\text { o }\end{array}$ & $\begin{array}{l}\text { Oे } \\
\text { ลे }\end{array}$ \\
\hline i & i & I & i & i & i & i & I & i & i & i & i & i & i & i \\
\hline
\end{tabular}

In the next step, the positive and negative ideal values are calculated. Table 4 shows these values. 
Table 4: Determining Positive and Negative Ideal Points

\begin{tabular}{|c|c|c|c|c|c|c|c|c|c|c|c|c|c|}
\hline & $\mathrm{X} 1$ & $\mathrm{X} 2$ & $\mathrm{X} 3$ & $\mathrm{X} 4$ & $\mathrm{X} 5$ & X6 & $\mathrm{X} 7$ & X8 & X9 & X10 & $\mathrm{X} 20$ & $\mathrm{X} 21$ & $\mathrm{X} 22$ \\
\hline & $\begin{array}{l}0 \\
\infty \\
\infty \\
\stackrel{0}{\vec{J}} \\
\stackrel{\vec{a}}{a}\end{array}$ & 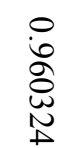 & 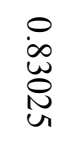 & $\begin{array}{l}\stackrel{0}{\sim} \\
\stackrel{0}{N} \\
\stackrel{+}{\sigma}\end{array}$ & 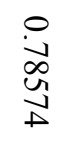 & $\begin{array}{l}\stackrel{0}{0} \\
\stackrel{0}{0} \\
\stackrel{W}{0}\end{array}$ & $\begin{array}{l}0 \\
\infty \\
\infty \\
\infty \\
\infty \\
+\infty\end{array}$ & $\begin{array}{l}0 \\
\dot{\infty} \\
\infty \\
\infty \\
\infty \\
\cup_{1}\end{array}$ & $\begin{array}{l}0 \\
\infty \\
\mathscr{O} \\
\stackrel{\square}{~}\end{array}$ & \begin{tabular}{l}
$\circ$ \\
$\stackrel{\infty}{J}$ \\
\multirow{\infty}{\infty}{}
\end{tabular} & 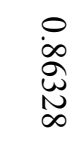 & $\begin{array}{l}0 \\
\stackrel{0}{0} \\
\stackrel{\sim}{\sim} \\
N\end{array}$ & 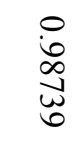 \\
\hline & $\begin{array}{l}0 \\
8 \\
8 \\
8 \\
\$\end{array}$ & 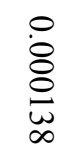 & $\begin{array}{l}0 \\
\dot{8} \\
\dot{8} \\
\text { 竞 }\end{array}$ & $\begin{array}{l}0 \\
\dot{8} \\
8 \\
\text { 离 }\end{array}$ & $\begin{array}{l}0 \\
\dot{8} \\
\dot{0} \\
\text { 足 }\end{array}$ & $\begin{array}{l}\stackrel{\circ}{8} \\
\stackrel{8}{0}\end{array}$ & $\begin{array}{l}\dot{0} \\
\dot{8} \\
\dot{0} \\
\text { a }\end{array}$ & $\begin{array}{l}\circ \\
\dot{8} \\
\stackrel{8}{0}\end{array}$ & $\begin{array}{l}0 \\
\dot{8} \\
\dot{1} \\
+\end{array}$ & $\begin{array}{l}\circ \\
\dot{8} \\
\stackrel{8}{0} \\
0\end{array}$ & $\begin{array}{l}\stackrel{\circ}{\circ} \\
\dot{\infty} \\
\stackrel{\infty}{\infty}\end{array}$ & $\begin{array}{l}\circ \\
\stackrel{8}{8} \\
\stackrel{8}{0}\end{array}$ & $\begin{array}{l}\text { O } \\
\dot{8} \\
0 \\
0 \\
\text { ur }\end{array}$ \\
\hline
\end{tabular}

In the next step, according to the equations (9), (10) and (11), the values of S, R, and Q are calculated and ultimately the options are ranked according to the $\mathrm{Q}$ values, and an option that allocates the minimum value of $\mathrm{Q}$ to itself is chosen as the best option. In table 5, the ranking of factors that affect the subscribers' preferences with respect to the obtained values of $\mathrm{Q}, \mathrm{S}$, and $\mathrm{R}$ can be observed.

Table 5: Ranking of Factors According to the Values Obtained from Q, S, and R

\begin{tabular}{|c|c|c|c|c|c|c|}
\hline & \multicolumn{2}{|l|}{$S$} & \multicolumn{2}{|c|}{$\mathrm{R}$} & \multicolumn{2}{|l|}{ Q } \\
\hline & Value & Rank & Value & Rank & Value & Rank \\
\hline $\mathrm{X} 1$ & 148.1825 & 22 & 39.94173 & 22 & 0.57321 & 22 \\
\hline $\mathrm{X} 2$ & 70.04258 & 12 & 34.81191 & 13 & 0.31377 & 12 \\
\hline $\mathrm{X} 3$ & 78.48523 & 19 & 37.58537 & 17 & 0.49208 & 17 \\
\hline $\mathrm{X} 4$ & 66.96011 & 9 & 33.35305 & 9 & 0.22148 & 9 \\
\hline $\mathrm{X} 5$ & 65.02836 & 6 & 32.36892 & 6 & 0.19016 & 6 \\
\hline $\mathrm{X} 6$ & 71.40525 & 15 & 34.53234 & 12 & 0.72753 & 20 \\
\hline $\mathrm{X} 7$ & 62.31354 & 3 & 31.04876 & 3 & 0.12380 & 3 \\
\hline $\mathrm{X} 8$ & 60.91357 & 2 & 30.46409 & 2 & 0.04962 & 2 \\
\hline $\mathrm{X} 9$ & 59.87528 & 1 & 30.01533 & 1 & 0.00000 & 1 \\
\hline X10 & 68.33047 & 10 & 34.08499 & 10 & 0.23199 & 10 \\
\hline X11 & 65.55258 & 7 & 32.65192 & 7 & 0.19275 & 7 \\
\hline $\mathrm{X} 12$ & 63.13823 & 4 & 31.48507 & 4 & 0.12739 & 4 \\
\hline $\mathrm{X} 13$ & 65.84231 & 8 & 32.78549 & 8 & 0.20299 & 8 \\
\hline X14 & 68.60071 & 11 & 34.11380 & 11 & 0.27804 & 11 \\
\hline $\mathrm{X} 15$ & 70.11906 & 13 & 34.84994 & 14 & 0.31514 & 13 \\
\hline X16 & 80.54692 & 21 & 39.94173 & 21 & 0.57162 & 19 \\
\hline $\mathrm{X} 17$ & 72.08889 & 16 & 35.81563 & 16 & 0.36378 & 15 \\
\hline X18 & 64.50105 & 5 & 32.13059 & 5 & 0.17000 & 5 \\
\hline X19 & 76.61532 & 17 & 38.01935 & 18 & 0.47484 & 16 \\
\hline $\mathrm{X} 20$ & 70.53123 & 14 & 34.96685 & 15 & 0.36019 & 14 \\
\hline $\mathrm{X} 21$ & 77.23236 & 18 & 38.22868 & 19 & 0.52569 & 18 \\
\hline $\mathrm{X} 22$ & 79.96907 & 20 & 39.52674 & 20 & 0.60903 & 21 \\
\hline
\end{tabular}


After ranking factors, importance-performance analysis has been used. In this method, by using IPA matrix, performance improvement solutions and the development of appropriate strategies is carried out. In this research, the five-point spectrum Likert's questionnaire (very low (1) to very high (5)) has been used to express the ratio of operators' performance. In order to determine the performance ratio, the mean of given responses from the performance questionnaire in relation to the factors affecting subscribers' preferences in selecting mobile phone operators has been calculated. Also, the values of Q obtained from the VIKOR method were used to determine the importance ratio. After inserting data in the importance-performance matrix and analyzing it, the factors that need to be improved and the necessary actions that should be taken on them are identified. The results of investigating importance-performance of the two operators through the IPA matrix can be observed in figures (3) and (4).

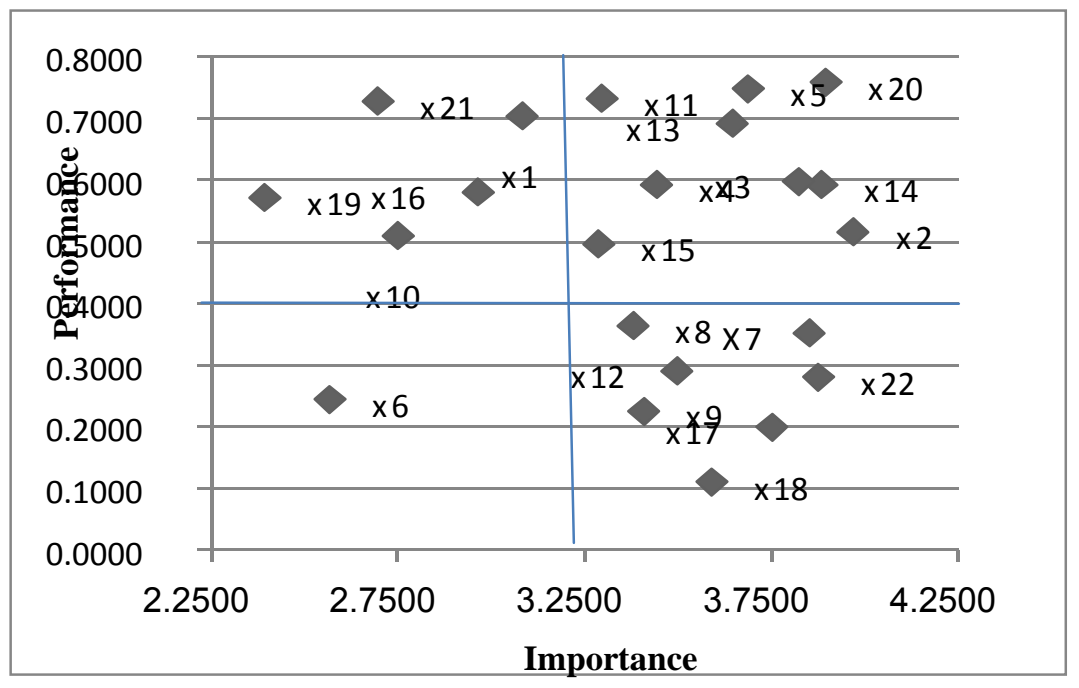

Figure 3: Importance - Performance Matrix of Hamrahaval

As it can be observed in figure 3, the criteria of X11, X13, X14, X15, X20, X2, X3, X4, and X5 are among the factors of high importance, and the performance of Hamrahaval operator in relation to these criteria is satisfactory for subscribers and represents the strength and competitive advantage of Hamrahaval. In the second quarter, the criteria of X19, X21, X1, X10, and X16 are located which are of less importance than the first quarter, but Hamrahaval has a high performance in relation to these criteria. In the third quarter, only X6 criterion is located; this criterion is located in the indifference region. In the fourth quarter, the criteria of $\mathrm{X} 8$, $\mathrm{X} 9, \mathrm{X} 12, \mathrm{X} 17, \mathrm{X} 18, \mathrm{X} 22$, and $\mathrm{X} 7$ are located which are of great importance, but the performance of Hamrahaval is poor in relation to them.

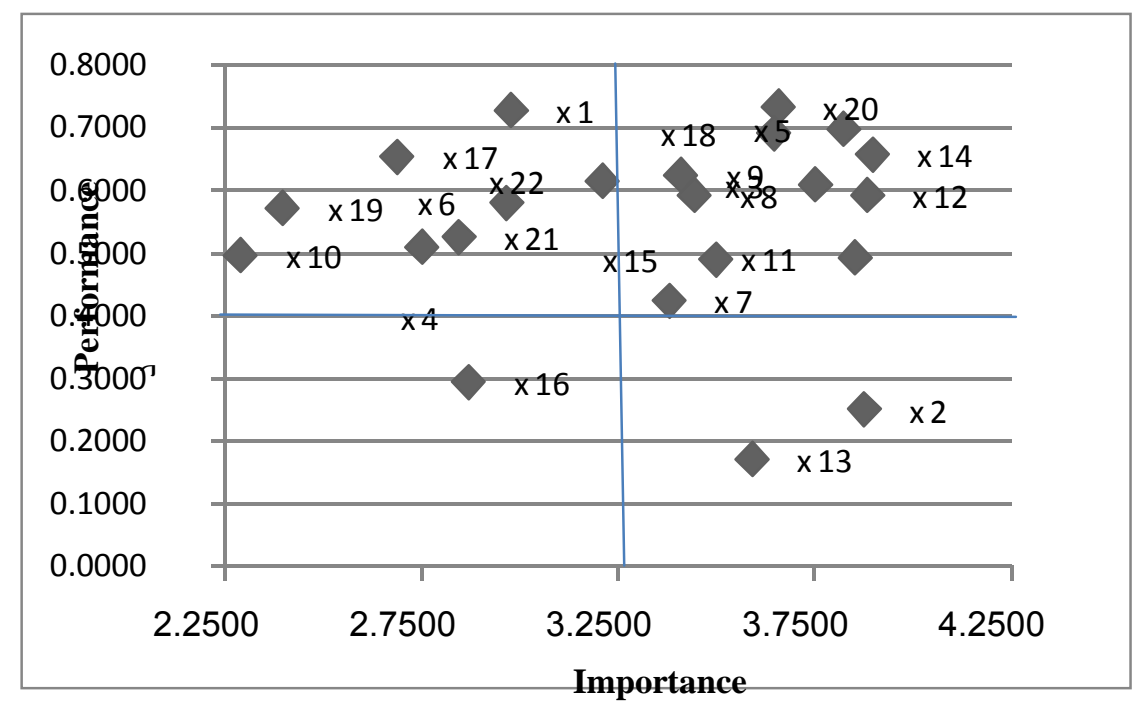

Figure 4: Importance - Performance Matrix of Irancell 
In the Irancell operator, the criteria of X8, X9, X11, X12, X14, X15, X18, X20, X3, X5, and X7 are among the factors that are located in the first quarter, and the performance of Irancell operator has been satisfactory for subscribers with respect to this criteria. In the second quarter, the criteria of X22, X1, X4, X6, X10, X17, X19, and X21 are located which are of less importance, but Irancell has a high performance in relation to these criteria. In the third quarter, only X16 criterion is located; this criterion is located in the indifference region, with low importance and performance. In the fourth quarter, the criteria of X2, and X13 are located that are of great importance, but the performance of Irancell is poor in relation to them.

\section{Discussion and Conclusion}

With regard to the mobile phone technology growth and the increasing uses of it and broad popular acceptance of this technology, the mobile phone market has become competitive. In the competitive market, there is an effort to attract new customer and, on the other hand, the existing customers should be preserved. The research has ranked the factors affecting subscribers' preferences in selecting mobile phone telecommunication operators by using the VIKOR method in the fuzzy environment. Based on the results obtained from the VIKOR method, the importance-performance matrix of operators was extracted. The results of importanceperformance matrix show that in the Hamrahaval operator "antenna coverage in the depth and height", "speed of performing services in the centers", "SIM card price", "the modernity of services based on the technology of the day", "the quality in providing value-added services", "performing services at every hour of the night and day" are among factors of great importance, but the performance of the company has been poor in relation to them. And also in the operator of Irancell, "offering awards and discounts on the use of services", and "calls price" have poor performance with respect to the high importance of factors.From the results obtained from the importance-performance analysis of Hamrahaval and Irancell, the weaknesses and strengths of these two operators are identified and if managers pay attention to remove the weaknesses, they can have a significant impact on the development of business in the organization. In the future researches the subscribers' preferences with regard to the age range can be investigated to make data more realistic.

\section{References}

[1] Rezaian, Sajjad, Karimi, Zahra, 2010, "Presenting the Model of Customers' Preferences in Choosing A Public Bank to Identify Improvement Opportunities", Quarterly Journal of Iranian Management Sciences, Second International Conference on Marketing of Financial Services, Tehran, Iran

[2] Shavandi, Hassan, 2006, "Fuzzy Sets Theory and Its Applications in Industries and Management Engineering", First Edition, Tehran, the Expansion of Basic Sciences

[3] Sheikhzadeh, Rajabali, Piltan, Akram, Shafiegol, Mehdi, Kaboli, Ali (2013), “Comparison of Customers' Satisfaction with Value Added Services of the Two Companies of Hamrahaval and Irancell”, Mobile Conference of Iran, Tehran

[4] Sabahi, Atefeh, 2009, "Comparative Investigation of Subscribers' Satisfaction with Mobile Phone Operators Services (Hamrahaval, Irancell), Case Study: Tehran Public Universities", Fourth International Conference on International Marketing Management

[5] Sehat, Saeed, Bajamalavi Rostami, Hamideh, Kashkoli, Mahboobeh, 2012, "The Effect of Marketing Mixtures on the Value of the Trademark of the Karafarin Insurance Company", Commercial Management, Vol. 4, No.1, pp. 71-90

[6] Mulla Ali Kei, Hamidreza, Ali Ahmadi, Alireza, 2002, "Prioritization of the Study Plans of the Telecommunication Development of the Country by Using Decision-Making Techniques with Multiple Criteria”, Quarterly Journal of Rahyaft, No. 27

[7] Mansoor, Samadi, 2007, "Consumer Behavior", Second Edition, Aiezh Publication

[8] Ahn, J., Hana, S., Lee, Y. (2006). Customer churn analysis: Churn determinants and mediation effects of partial defection in the Korean mobile telecommunications service industry.Telecommunications Policy, 30, pp.552-568

[9] Azzopardi,E., Nash, R. (2012). A critical evaluation of importance-performance analysis.Tourism Management, pp. 1-12

[10] Babakus, E., and Boller, G.W. (1992).An empirical assessment of the SERVQUAL Scale, Journal of Business Research, 24, pp.235268.

[11] Choi, S. K., Lee, M. H., Chung, G. H. (2001) Competition in Korean mobile telecommunications market: Business strategy and regulatory environment. Telecommunications Policy, 25(1-2), pp.125-138.

[12] Eshghi, A., Roy, S. K. Ganguli, Sh. (2008). Service Quality and Customer Satisfaction: an Empirical Investigation in Indian Mobile Telecommunication Services. Marketing Management Journal, 18(2), pp. 119-144.

[13] Fullerton, R. A., Punj G. (2004). Repercussions of promoting an ideology of consumption: consumer misbehaviour, journal of Business Research, 11(57),pp.1239-1249.

[14] Gerpott, T. J., Rams, W., and Schindler, A. (2001).Customer retention, loyalty, and satisfaction in the German mobile cellular telecommunications market.Telecommunications Policy, 25, pp.249-269.

[15] Gunjan, M., Amitava, M., Abhishek, N. \& Soumyadeep, S. (2011). Consumer Behavior towards Mobile Phone Service Provider - An Empirical Research on Mobile Number Portability in India. Advances In Managemen, 4 (6), pp.44-49.

[16] Hafeez, S. Hasnu, S. (2010). Customer Satisfaction for Cellular Phones in Pakistan: A Case Study of Mobilink. Business and Economics Research Journal, 1 (3), pp.34-44.

[17] Huang, J. J., Tzeng, G. H. and Liu, H.H. (2009), A Revised VIKOR Model for Multiple Criteria Decision Making - The Perspective of Regret Theory, Communications in Computer and Information Science, 35 (11), pp.761-768

[18] Jahanzeb, S., Tasneem, F. Bashir-Khan, M. (2011). An empirical analysis of customer loyalty in Pakistan's telecommunication industry. Journal of Database Marketing \& Customer Strategy Management, 18 (1), pp.5-15.

[19] Kim, H., Kwon, N. (2003). The advantage of network size in acquiring new subscribers. Information Economics and Policy,15(1), pp.17-33.

[20] Kim, H., Yoon, C.(2004). Determinants of subscriber churn and customer loyalty in the Korean mobile telephony market. Telecommunications Policy, 28, pp.751-765.

[21] Kim, M. K., and Jeong, D. H. (2004).The effects of customersatisfaction and switching barriers on customer loyalty inKorean mobile telecommunication services. Telecommunications Policy, 28(2), pp.145-159.

[22] Krishnan, R. \& Kothari, M. (2008). Antecedents of Customer Relationships in the Telecommunication Sector: An Empirical Study. The Icfai University Press, pp.38-59. 
[23] Liang, D., Ma, Zh. Qi, L. (2012). Service quality and customer switching behavior in China's mobile phone service sector. Journal of Business Research. Lim, H., Widdows, R.\& Park, J. (2006). M-loyalty: winning strategies for mobile carriers. Journal of Consumer Marketing, 23 (4), pp.208-218.

[24] Martilla J. A., James J. C. (1977). Importanceperformance analysis. Journal of Marketing, 41(1), pp.77-79.

[25] Negi, R. (2009). Determining Customer Satisfaction Through Percieved Service Quality: A Study of Ethiopian Mobile Users. International Journal of Mobile Marketing, 4 (1), pp.31-38.

[26] Pezeshki, V., Mousavi, A.R. Grant, S. (2009). Importance-performance analysis of service attributes and its impact on decision making in the mobile telecommunication industry. Measuring Business Excellence, 13(1), pp.82 - 92.

[27] Santouridis, I. Trivellas, P. (2010). Investigating the impact of service quality and customer satisfaction on customer loyalty in mobile telephony in Greece. The TQM Journal, 22(3), pp.330 - 343.

[28] Song, J. D., Kim, J. C. (2001). Is five too many? Simulation analysis of profitability and cost structure in the Korean mobile telephone industry. Telecommunications Policy, 25(1-2), pp.101- 123.

[29] Tang, H.,Kambris, Z., Lemaitre, B., Hashimoto, C. (2008). A serpin that regulates immune melanization in of the respiratory system Drosophila, journal of BU, 15(4), pp.617-626.

[30] Zadeh, L.A. (1965). Fuzzy sets, Information and Control, 3(8), pp. 338-53. 